Albuminuric Botinitis and Arotomia.-The importance of alhuminuric retinitis and its serious nature have been.long recognized, but the pathology of the lesion has remained obscure. Among the suhstances wbich may be retained in the organism during the course of nephritis, two have heen the subject of specinl study in recent years-chloride of sodium and urea. Wmar, Mornx, and Weill (Ann. d'ocul., May, 1910,354 ) have ohserved 71 cases of nephritis of different types, of which 17 were affected with retinitis. There was no relation whatever between the retinal lesion and the retention of chlorides in any of these cases, while all of them shotied more or less pronounced retention of urea.

\title{
PATHOLOGY AND BACTERIOLOGY.
}

\author{
TNDER THE CHAROE OF \\ WARFIELD T. LONGCOPE, A.D.,

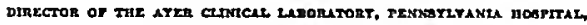 \\ NSSTSTED AT \\ G. CANBY ROBINSON, ML, ,

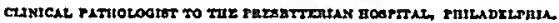

The Glycyl-Iryptophan Test for Carcinoms of the Stomach. The application to the diagnosis of cancer of the stomach of the fact that malignant tumors contain a peptid-splittiog ferment, by NeUBaUER and Frscher (Deut. Arch. f. klint. Ifed., 1909, xcvii, 499) was reported .in this Journal (1910, cuxir, 284). They made use of a polypeptid, glycyltryptopban, the split product of wbich, tryptopban, is casily recognized by a color reaction with bromine. Trypsin regurgitated from the duodenum and hlood will hoth accomplisb this splitting and must be ruled out-hy the tests for bile and for occult blood. The presence of tryptophan itself in the stomach must he excluded. The development of peptid-splitting haeteria is prevented by toluol.

LrLe and KOBER (New York MIed. Jour., 1910, xci, 1151) have applied the test in 21 cases of suspected carcinoma of the stomach. The test was positive in 10 cases, 6 of which have been proved carcinoma of the stomach by operation. Of the 11 negative cases, 5 have been eonfirmed hy autopsy or subsequent course. The authors found the regurgitation of trypsin the grentest source of error. They do not believe the test for hile sufficiently sensitive for this determinatioo. They have proved the presence of trypsin when the tests for hile were negative. So they advise giving the test meal in the afternoon after a purge the night before. They believe that no deductions should be drawn from less than three tests.

The Rapid Diagnosis of Diphtheris by Fixstion of the Complement.-The present knowledge of the occasional unfortunate accidents accredited to anaphylaxis has made. the indiscriminate employment of antidiph- 
theric serum a dangerous ooe. A useless injection will develop this hypersensitiveness in a patient and expose him to the possihility of later accidents, as well as diminish the duratioa of the curntive setion of later serum therapy. The hacteriological diagnosis which has come to be relied upon necessitate's a delay of eighteen hours. With this in mind, Weilue-Hazle and Brock-Miches (Bull. et mem. de la Soc. med. hop. de Par., 1910, xxviu, 707) have made use of the method of Bordet and Gengou, of fixation of the complement, for a rapid, early, sure diagnosis. As antigen they employed an emulsion in salt solution of the mucus obtained from the tonsils and pharynx on a cotton tampon. Antidiphtheric serum from the Pasteur Institute contained the amhoceptor, and fresh rahhit serum the complement. A sheep hemolytic system was employed. Trenty-five cases of diphtherin resulted in fixation; 10 cases of non-diphtheritic angina, 9 of measles, and 3 of scarlatina showed bemolysis and were negative.

The Bactericidal Substancas Ertractid from Normal Lenkocytes. ZINSSER (Jour. Mred. Research, 1910, nxii, 397) bas iovestigated the properties of the hactericidal suhstances contained in normal leukocytes, especinlly in regard to their effect on Staphylococcus pyogenes alureus and Bacillus typhosus. The substanes were obtained from leukocytes of rabbits hy aqueous extraction and extraction in salt solution after. freezing the leukocytes. The two methods gave extracts with practically tbe same bactericidal properties, wbich wcre tested by adding the extract to an equal port of a foirly constant bacterial emulsion. A fixed amount of this mixture was removed and plated in agar at various intervals. There was found a considerable uniformity in the action of the various lots of such extracts upon the same strains of the same organism, nor did various strains of the same organism sbow any marked variations io their susceptibility to the bactericidal substances cootained in the extract. These suhstances ore apparently distinct from and differently constituted to the bactericidal substances of their serum, not being destroyed by temperatures below $75^{\circ}$ and after henting to $80^{\circ}$ activation does not take place by the addition of fresh extract. There was no evideoce that the leukocytic extracts contained complement, either for the activation of hactericidal antibodies in serum or for hemolytic amboceptors. Quantitatively these hactericidal suhstances are insignifieant compared with the hactericidal powers of normal serum, and it is unlikely that they ore responsible, except in a purely secondary way, for the curative results ohtained in infections in animals and man. Teukocytes from immunized animals yield an extract with no stronger hactericidal properties than do those from normal animals, and it would seem that these suhstances, as contained in the leukocytes, may be at all times simply sufficient for the destruction of the limited numbers of hacteria which can be ingested hy the cell, and have no quantitative relationship for the specific immunity acquired hy animals or human beings. during their reactions against spontaneous or experimental infection.

Antolysis of Pneumococei-Rosman (Jour. Amer. Afed. Assor.,1910, liv, 1943), makes a preliminary report of some very interesting and important results which have been ohtained from his work on the 